\title{
DIGITAL GAMES IN EDUCATION FROM THE PERSPECTIVE OF TEACHERS
}

Karel PICKA*, Masarykova Univerzita v Brně, Česká republika

Přijato: 5. 12. 2016 / Akceptováno: 8. 2. 2017

Typ článku: Výzkumná studie ${ }^{1}$

DOI: $10.5507 /$ jtie.2017.003

Abstract: The research aims to describe how teachers perceive the involvement of digital games in the classroom and whether and how it is used in their teaching. The work is inspired by other studies from abroad, which describe teachers' approach to engaging digital games in the educational process. Especially in the USA, Great Britain or Sweden and Singapore. Data were collected using a questionnaire, which was attended by 586 respondents from across the country. The survey found especially how often, how and with what difficulties the teachers use digital games in their practice or why they not use this method.

Key words: digital games, ICT, game-based learning, questionnaire survey

\section{DIGITÁLNÍ HRY VE VÝUCE Z POHLEDU UČITELŮ}

Resumé: Cílem výzkumu bylo zjistit, jak učitelé vnímají zapojování digitálních her do výuky a jestli a jak učitelé ve výuce digitálni hry použivají.

Práce je inspirována jinými výzkumy ze zahraničí, které popisuji učitelský př̀istup $k$ zapojováni digitálních her do vzdělávacího procesu. Především v USA, Velké Británii, Švédsku či Singapuru. Data byla sebrána pomocí dotazníkového šetření, kterého se zúčastnilo celkem 586 respondentũ z celé ČR. Výzkumné šetřeni tak predevším zjistilo jak často, jakým zpưsobem a s jakými obtižemi učitelé digitální hry využivaji ve své praxi, popř́padě proč tuto metodu nevyuživají.

Klíčová slova: digitální hry, ICT, game-based learning, dotazníkové šetření

\footnotetext{
${ }^{1}$ Studie vznikla za podpory projektu MUNI/A/0985/2015

* Autor pro korespondenci 318732@mail.muni.cz
} 


\section{1 Úvod}

V posledních dvaceti letech se dají digitální hry považovat za jeden z inovujících prvků vzdělávání, který zažívá poměrně stabilní vzestup (Gee, 2004; Futurelab, 2006; Ke, 2008). Digitální hry jsou ve společnosti především mladých lidí zásadním kulturním fenoménem a komunikačním kanálem, který je využíván v rozvinutých zemích (ISFE, 2012; ICILS, 2013). Hry jsou v současnosti používány s pozitivními výsledky v mnoha typech školního vzdělávání. V mateřských školách (Hsiao \& Chen, 2016) mohou sloužit např́klad ke zlepšení prostorové koordinace nebo hbitosti. Na vysokých školách mohou plnit jak úlohu demonstrační (např. Adams, 1998), tak bývají využity i k podpoře rozvoje konkrétních znalostí a dovedností (Taekman \& Shelley, 2010; Allane, 2010). Pro žáky, především základních a středních škol, mají hry výhody spočívající zejména ve větší zábavnosti výuky, jsou schopny více upoutat pozornost žáka a více ho tak i motivovat ke vzdělávacímu obsahu (Hiller, et al., 2016).

Z odborné literatury i z populárních periodik můžeme vysledovat velice různorodé používání digitálních her. At' již jde o použití čistě komerčních her ve výuce (Adams, 1998; Tannahill et al, 2012; Short, 2012), her vytvořených cíleně pro vzdělávací účely (Philpot, 2005; Charsky, 2010, Deveau et al., 2014 v českém prostředí pak také Brom, Šisler \& Slavík, 2010) nebo například využívání virtuálních světů ${ }^{2} \mathrm{~s}$ herními prvky (Calongne, \& Hiles, 2007; Hamilton, et al., 2014). Lze pozorovat, že snaha o zapojování těchto prvků do výukové procesu v různých jeho fázích je přítomna. $Z$ výše popsaných zdrojů (a z dalších v této studii) je rovněž patrné, že i odborná veřejnost si tématu všímá a snaží se tyto tendence ve vzdělávání zkoumat a řešit.

I přes velké počáteční nadšení některých propagátorů digitálních her ve vzdělávání a některých výzkumníků (Prensky, 2001; Gee, 2004; Tannahill et al., 2012), byla úspěšnost zapojování her do výuky přinejmenším rozporuplná. I když zde již delší dobu bylo možné nalézt pozitivní výsledky her ve vzdělávání, jednalo se spíše o jednotlivé př́klady než o jasný důkaz rozvinutého trendu (Adams, 1998; Robertson \& Howells, 2008; nebo v českém prostředí např́iklad Šisler, 2012).

\section{Digitální hry ve třídách primárního a nižšího sekundárního vzdělávání}

Vzhledem k tomu, že výzkumné šetření je zaměřené na učitele základních škol, jsou i teoretická východiska této práce zaměřena směrem k primárnímu a nižšímu sekundárnímu vzdělávání.

Nejčastěji zastoupeným typem výzkumu v rámci zvoleného omezení je šetření týkající se zlepšení dosahovaných výsledků v konkrétním předmětu. Ačkoliv výzkumy často sledují i jiné faktory (motivace, pozornost), primárně zjišt’ovaným dopadem digitálních

\footnotetext{
2 Virtuální světy sdílejí s klasickými hrami (hlavně s masivně-multiplayerovými tituly) mnoho podobností, některé obsahují i oblasti, kde dochází ke klasickým herním situacím (sportovní utkání, závody...). Tyto obrovské světy zaměřené spíše na komunikaci mezi uživateli než na hru jako takovou začaly poskytovat prostor i pro vzdělávací aktivity. Světy jako Second Life, Active Works, SmallWorlds a další nabízí totiž obrovský prostor, kde je možné nejen vystavět virtuální univerzitní kampus s přednáškovými sály, ale především poskytují možnosti simulace probíraných jevů a to jak z humanitních věd (virtuální antický Rím, či Shakespearova tragédie) tak z technických oborů (obrovský virtuální počítač, který je možné s vyučujícím projít a zblízka vidět veškeré mikroskopické detaily nebo simulování vesmírných jevů).
} 
her je právě jejich př́nos na straně osvojení si požadované látky. Ve většině výzkumných studií je možné nalézt alespoň nějaký pozitivní ohlas vůči použití digitálních her, ovšem výsledky na kognitivním poli jsou nekonzistentní. Např́klad Ke (2008a) uvádí, že při testování několika her pro cvičení matematických úloh lze pozorovat větší kognitivní zlepšení jen v některých oblastech (oproti procvičování klasickým způsobem - za pomocí psaní př́íkladů do sešitu), nicméně kvalitativní část výzkumu dokládá mnohem větší motivaci a nadšení žáků i při dlouhodobějším použití. V tomto př́ípadě je výsledek možno uvádět jako veskrze pozitivní, jelikož i když nedošlo $\mathrm{k}$ výraznému zlepšení ve znalostech, v žácích již procvičování matematiky nevyvolávalo negativní postoje. Podobně dopadl i pozdější výzkum stejného autora (Ke, 2008b), kde ovšem autor připomíná, že ne každá hra je pro učení vhodná a je potřeba citlivého př́stupu designéra hry. Především pak v částech, kde jsou žákům vysvětlovány úkoly $\mathrm{k}$ vyřešení, popř́padě i tvorba herních mechanik, která musí být dostatečně poutavá. Za velice důležitý poznatek z tohoto výzkumu je také možné považovat názor autora, že vedení žáků zkušeným pedagogem v průběhu interakce se hrou poskytuje mnohem širší porozumění tématu a umožňuje lepší vhled do problému, kde si žák neví rady.

Jiný př́stup byl zvolen při výzkumu tvorby herního obsahu samotnými žáky (Robertson \& Howells, 2008). Herní element je tu zastoupen ne pouze hraním hry, ale i její aktivní tvorbou ${ }^{3}$. V tomto konkrétním př́ípadě se jedná o využití komerční počítačové hry Neverwinter Nights. Žáci zde tvoří vlastní př́iběhy, postavy i herní svět. Jak autoři v závěru své práce poznamenávají, takovýto př́istup se jen těžko dá zařadit do jedné položky v rámci kurikula, jelikož se zaměřuje na rozvíjení jak technických dovedností, tak např́iklad čtenářské gramotnosti i dalších prvků. Práce sbírala data po delší dobu (několik měsíců), přesto trpí poměrně malým zkoumaným vzorkem. Větší počet účastníků měl pozdější výzkum Dennera (2012), který již nepoužívá modifikovanou komerční hru, ale pro žáky přizpůsobené vývojářské prostředí. Autor sice uvádí, že pro žáky bez jakékoliv předešlé zkušenosti s programováním bylo ze začátku obtížné v tomto nástroji pracovat, pod vedením pedagoga docházelo však k poměrně rychlému pokroku. Žáci byli v průběhu schopni stvořit i několik různých her, ve kterých byli autory jak po stránce programové, tak grafické.

Na problém zapojení her nahlíží i nedávná studie, zkoumající roli adaptivního učení s pomocí digitálních her (Hwang, et al., 2012). Autoři zde uvažují nad učebními styly dle Feldera a Silvermanové (1988) a v této souvislosti tvoří hru, která by měla využívat metody Adaptive learning. Hra, která je zaměřená na výuku biologie, se přizpůsobí

3 Zajímavých výsledků se podařilo dosáhnout při výzkumu schopnosti dětí předkládat vlastní matematické problémy (Chang, et al., 2012). Tato metoda není úzce spjata s digitálními hrami a její idea spočívá spíše ve změně perspektivy, kdy žák sám designuje vlastní (funkční) matematické úlohy. Ve výzkumu je ovšem jako stěžejní prvek použita digitální počítačová hra, která tento způsob myšlení rozvíjí. Je však nutné dodat, že tvorba úloh studenty je sice prezentována hrou (a jejich následné řešení také), nicméně hra sama o sobě je poměrně chudší co se týče čistě herních prvkủ a má spíše blízko k učení programování, včetně možnosti ověřovat svoje závěry a testovat je. 
učebnímu stylu žáka (dle Feldera a Silvermanové rozdělené na sekvenční a celkový typ) a dle toho prristupuje k zadávání jednotlivých úkolů, testů a dalších aktivit. Autoři dospěli k velice pozitivním výsledkům experimentální skupiny nad kontrolní skupinou (opět formou pre a posttestu), a to jak $\mathrm{v}$ rovině kognitivní, tak $\mathrm{v}$ motivaci žáků $\mathrm{k}$ dalšímu vzdělávání se v tématu. I zde je však potřeba dalš́ho výzkumu, zejména pak dlouhodobě orientovaného a s širším zkoumaným vzorkem. Dopad na studium biologie rovněž řešila starší studie (Anetta, et al., 2008), která ovšem nedochází k tak pozitivním, kognitivně zaměřeným výsledkům jako Hwang (2012), ale i zde je u žáků je pozorována mnohem větší motivace ke studiu a práci se vzdělávacím materiálem ve formě hry. Podobné závěry obsahuje i starší výzkum z tureckých škol (Tüzün, 2008), který se zaměřuje na výuku zeměpisu na základní škole. V této studii žáci vykazují větší zájem o probíranou problematiku, menší únavu a i o něco lepší výsledky než kontrolní skupina, která hry ve výuce nevyužívá. Zde je ovšem nutno dodat, že experimentální skupina byla výběrová. Sice především na základě znalosti anglického jazyka, ale i tak mohlo dojít ke zkreslení výsledků.

Kromě výzkumů, které se specializují na vzdělávání v konkrétních předmětech, vznikají rovněž takové, které se zaměřuí na možnosti her ke zlepšení motivace a zájmu žáků, jejich většího ponoření se do probírané látky a rozvíjení dalšího zájmu o problematiku. Výzkumná práce Millera a Robertsona (Miller \& Robertson, 2009) vyvozuje na základě práce se 71 žáky, že použití her ve výuce matematiky u nich nejen zlepšilo a zrychlilo matematické operace, ale při delším zapojení (období deseti týdnů) her do běžné výuky (jako část hodiny) výrazně zvýšilo jejich sebevědomí a sebehodnocení v tomto předmětu oproti kontrolní skupině, která nijak nezměnila svoje metody výuky.

\section{Názory a zkušenosti učitelů na zapojení digitálních her v zahraničí}

VČeské republice zatím výzkumy, které by řešily míru a způsob zapojování digitálních her do výuky, chybí. Tématu se dotkla (i v rámci České republiky) mezinárodní studie ICILS 2013, jejímž cílem ovšem nebyly primárně digitální hry (Basl, et al., 2014). Nálezy v této studii byly pro digitální hry ve vzdělávání poměrně nelichotivé, průměrná míra využívání byla jen okolo $5 \%$. Ryze české výzkumné práce v ČR samozřejmě najít můžeme (např. Brom, Buchtová, Šisler \& Palme, 2014; Brom, Šisler \& Slavík, 2010), avšak zatím zde není žádná, která by zkoumala čistě názory a postoje učitelů a četnost zapojování digitálních her do výukové praxe.

V zahraničí je situace poněkud jiná. Mnoho západních států má díky rozdílné sociokulturní a ekonomické historii jiný prrístup k ICT ve vzdělávání. Prvním zaváděním ICT do vzdělávání si západní státy Evropy nebo severní Ameriky prošly již v osmdesátých letech 20 . století, kdy se začaly na počítačích objevovat i první vzdělávací počítačové hry. Je proto logické, že i výzkumná šetření a vědecké práce, zabývající se využíváním digitálních her ve výuce, jsou v současnosti mnohem více př́tomné v západních zemích.

Jedna z prvních velkých studí, které se zaměřují na toto téma (Futurelab, 2009), popisuje situaci ve Velké Británii. Podstatná je jednak její šíre, ale především velký zkoumaný vzorek (n>1600) učitelů. Ze studie vyplývá, že $35 \%$ z dotázaných učitelů již někdy ve své praxi digitální hru použilo, a patrně není zásadním zjiššením, že ve větší míře to byli účastníci mladší věkové kategorie (do 44 let). Mnohem zásadnější zjištění této studie je poměrně pozitivní ohlas her, kdy $60 \%$ z dotázaných plánuje digitální hry použít 
znovu (nebo to alespoň poprvé zkusit), zatímco pouze $19 \%$ tuto možnost nevidí jako reálnou. Mezi nejčastější odpovědi na otázku, proč se použití digitálních her pro vzdělávání jeví jako kvalitní metoda výuky, patří to, že spatřují mnohem větší motivaci a zájem dětí o látku při práci se hrou nebo že toto médium je žákům blízké. Ze studie též vyplývá, že učitelé považují jako velký př́nos her zlepšení schopností žáků v oblasti ICT (74 \%), zlepšení motorických dovedností jako je reakční čas, koordinace oka a ruky ( $85 \%)$ nebo myšlení vyššího řádu, jako je strategické myšlení (66 \%). Nemalá část z dotázaných se nicméně obává, že hry by mohly působit i antisociálně, převážně izolovat jedince, zvyšovat jeho agresivitu, popř́padě snižovat empatické dovednosti (44 \%). I přes možná negativa her však dotázaní učitelé spatřovali jako největší překážky v zapojení her do výuky jejich vysokou cenu (74 \%) a problémy s licencováním $(69 \%)$. Nemalé procento $(51 \%)$ se rovněž obávalo možného nevhodného obsahu ve hrách.

I když je tato studie jistě významná svým počtem účastníků a odpovědí na některé bazální otázky, prakticky se nevěnuje dalším problémům. Největší limitace studie spočívá v jejím minimálním záběru mezi učiteli, kteří hry používají, a dalším výzkumu v otázkách, navazujících na kladnou odpověd' hned v první otázce výzkumu. Není tak zjištováno, jak často a jaké druhy her ve své výuce používají, popřípadě $\mathrm{v}$ jakých předmětech $\mathrm{k}$ nasazení her do výukové praxe nejčastěji dochází nebo jakým typům studentů nejvíce nasazení digitálních her prospělo.

Do mnohem větších detailů jde poměrně nedávná studie (Takeuchi \& Vaala, 2014) z prostředí amerických škol. Počet účastníků studie je zde menší (n=694), ale i tak poměrně vysoký. Výzkum ř́ká, že $74 \%$ z dotázaných učitelů již někdy ve vyučování digitální hru použilo a $54 \%$ je používá alespoň jednou do týdne. Za povšimnutí také stojí, že takřka polovina učitelů $(43 \%)$, která hry do výuky zapojuje $(\mathrm{n}=513)$, používá hry k pokrytí znalostí přímo vyžadovaných kurikulem, 17 \% učitelů je využívá $\mathrm{i} k$ hodnocení znalostí a dovedností žáků. Učitelé v drtivé většině $(81 \%)$ používají hry přímo určené pro vzdělávání, jen menšina používá hry vyloženě komerční $(8 \%)$ nebo komerční hry upravené pro vzdělávací potřeby ( $5 \%$ ). Učitelé zde také vnímají hry jako efektivní, a to především v matematice $(90 \%)$, informatice ( $85 \%$ ), jazycích $(82 \%)$ a některých dalších. Naproti tomu ve výtvarné a hudební výchově, poprípadě ve výchově ke zdraví (Healthy Habits) většinou hry jako prínos nevnímají. Ve výsledku se však $78 \%$ z dotázaných shoduje, že hry mají pozitivní dopad na zlepšení znalostí žáků a 73 \% se domnívá, že použití her nemá negativní vliv na problematické chování v hodinách.

Oproti tomu novejjši výzkum (Watson \& Yang, 2016), který ale operuje s podstatně menším vzorkem účastníků $(\mathrm{n}=104)$, se zaměřuje výhradně na obtíže, které učitelé mají/měli se zapojováním digitálních her a tak nachází překážky v jiných oblastech. Jako největší problémy související se zapojováním digitálních her byly indikovány většinou ty, které byly spjaty s malou edukační hodnotou her, obtížemi se zvládnutím a řízením tř́dy a většina učitelů kritizovala nedostatečný hardware a finanční podporu na tento druh výuky. Rozdíl oproti předešlé studii (Takeuchi \& Vaala, 2014) je také možné spatřovat $\mathrm{v}$ tom, že $\mathrm{v}$ ní byli zařazeni pouze učitelé $\mathrm{z}$ nižších ročníků $(\mathrm{K}-8)$, zatímco zde i učitelé $\mathrm{z}$ amerických středních škol (K-12). Jak studie podotýká, starší studenti mají od digitálních 
her větší očekávání, než jejich mladší spolužáci. Obtíž studie Watsona a Yanga je však $\mathrm{v}$ tom, že prakticky nerozlišuje mezi hrami komerčními a vzdělávacími ${ }^{4}$.

Širší zkoumaný vzorek, co do různorodosti učitelů, byl zahrnut ve starším výzkumu v Singapurských školách (Koh, et al., 2012). Účastníci byli vybráni napříč všemi stupni základních a středních škol $(\mathrm{n}=479)$, což do jisté míry opouští segment této práce, nicméně vzhledem $\mathrm{k}$ malému počtu studií na toto téma byla zařazena. Použití digitálních her je zde poměrně často zastoupeno (58 \%), ovšem je potřeba říct, že i když velká část učitelů v dotazníkovém šetření udává, že hry používá, zároveň udává, že jen velice zřídka (59\%). Jen velice málo z dotázaných užívá hry častěji než jednou týdně (6\%). Jako hlavní bariéru učitelé v Singapuru vidí především nedostatek času s hrami efektivně pracovat, vysokou cenu a obavu ze špatné reakce rodičủ žáků. Výzkum z amerických škol (Proctor \& Marks, 2013) se zaměřil na dotazování učitelů (n=259), kteří byli v letech 1996 - 2009 ocenění cenou Milken Educator Award. Učitelé zde označují hry jako pozitivní př́nos pro výuku, který je navíc velice snadný k využití (doslovně easy to use), a $60 \%$ z dotázaných je pravidelně využívá ve své praxi. Tato studie je samozřejmě velice specifická, protože účastníci jsou vybráni pouze z řad oceněných pedagogů, není tedy možné výsledky tohoto výzkumu nějak rozšiřovat na běžnou situaci v amerických školách.

Další výzkum provedený na amerických školách (Ruggiero, 2013) zkoumal poměrně širokou skupinu účastníků $(\mathrm{n}=1704)$, ovšem velká část $\mathrm{z}$ nich byli studenti učitelství $(\mathrm{n}=656)$. Je uvedeno, že $46 \% \mathrm{z}$ dotázaných hry použivá, oproti tomu $76 \%$ z dotázaných studentů učitelství se přiklání $\mathrm{k}$ tomu, že by hry chtěli využívat v budoucnu ve své praxi. Tento výsledek se poměrně různí ze studie Takeuchi \& Vaala (2014). Je ale možné, že je to způsobeno poměrně malým počtem otázek v dotazníku (4) a především nejasností první otázky, ze které není patrné, jestli se autorka ptá, zdali alespoň někdy použili digitální hry ve výuce nebo je používají v nějaké pravidelnosti.

Vzhledem $\mathrm{k}$ velice malému počtu výzkumů, které by se zajímaly o využívání digitálních her ve vzdělávání př́mo učiteli a jejich názorů a zkušeností, je zde několik, které podobné otázky kladou právě studentům učitelství. Kromě výše zmíněného výzkumu (Ruggiero, 2013) můžeme najít pozitivní odpovědi v několika dalších výzkumech právě mezi studenty učitelství (Can \& Cagiltay, 2006; Zheng \& Young, 2006; Pastore \& Falvo, 2010; Karadag, 2015). Z uvedených studií je patrné, že digitální počítačové hry budou zřejmě $\mathrm{v}$ budoucnu trendem, který bude učiteli minimálně zkoušen. Je proto vhodné, aby měli metodickou podporu a hry tak mohly být pro potřeby vzdělávání použity co možná nejúčelněji.

\section{Metodologie}

V rámci této studie bylo provedeno výzkumné šetření, jehož záměrem bylo objasnit pohled českých učitelů na digitální hry ve školním prostředí. Cílem výzkumu bylo zjistit, jak učitelé vnímají zapojování digitálních her do výuky a jestli a jak učitelé ve výuce digitální hry používají. V tomto výzkumu můžeme vidět návaznost na zahraniční práce

\footnotetext{
${ }^{4}$ Vzdělávací hry mají povětšinou méně problémů spojených s nedostatečným hardwarovým zázemím (nejsou tak výpočetně náročné, počítají s omezenějšími HW prostředky na školách), zatímco komerční hry ze své podstaty tyto náležitosti nerespektují.
} 
zmíněné výše, které se o obdobnou sondu snažily v rámci jiných zemí (např. Ke, 2008; Futerelab, 2009; Takeuchi \& Vaala, 2014; Watson \& Yang, 2016 a další).

Výzkumné šetření mezi pedagogy spočívalo ve sběru dat pomocí dotazníku, který obsahoval 41 položek, z čehož 20 bylo položek hodnocených dle pětibodové Likertovy škály (souhlasím - spíše souhlasím - nevím - spíše nesouhlasím - nesouhlasím), 21 polouzavřených a uzavřených otázek a jedna otázka otevřená, určená k vlastnímu vyjádření. Dotazník byl distribuován online v interaktivní formě. Data byla sbírána v období od 1. 6. 2016 do 3. 7. 2016. Interaktivní forma dotazníku spočívala v tom, že dle rozřazovací otázky vybral dotazník respondentovi jen př́slušné otázky. Školy, ze kterých respondenti pochází, byly vybírány dle toho, v jakém kraji a $v$ jak velké obci se škola nachází, aby bylo možné co nejlépe rozvrstvit šetření mezi většinu krajů v ČR a zároveň postihnout i rưzné velikosti obcí. Výběr škol byl proveden na základě dostupnosti, tedy jestli bylo možné sehnat kontaktní údaje na pedagogické pracovníky školy, nicméně nebyly zde žádné požadavky na konkrétní školu. Vzhledem k relativně malé návratnosti dotazníku byl výběr škol také upravován podle počtu získaných respondentů v jednotlivých krajích v průběhu dotazníkového šetření. Pro usnadnění vyhledávání škol byl použit online nástroj ,,mapa škol ${ }^{* 5}$, dle kterého bylo možno školy dohledat na internetu. Pro kontaktování respondenta byla použita jeho pracovní e-mailová adresa, nalezená na webové prezentaci školy, přičemž jistá část e-mailových adres byla shledána nefunkční. Celkem byl dotazník zaslán na 6270 unikátních e-mailových pracovních adres a do konečného výběrového souboru se vyplněním dotazníku dostalo 586 respondentů. Návratnost dotazníku tedy činí jen 9,3\%. Toto nízké číslo je ovlivněno nedostupností některých adres a také pravděpodobným přesycením základního souboru podobnými požadavky.

Dotazník obsahoval několik částí, kdy v první části byly zkoumány demografické a kontextové informace o respondentovi (velikost obce, pohlaví a délka učitelské praxe, předměty, které jsou respondentem vyučovány). Jednotlivé položky dotazníku byly vytvářeny $\mathrm{s}$ ohledem na téma této práce a byly výrazně ovlivněny existujícími studiemi, které jsou probírány výše (viz kapitola 3). Otázky kladené v dotazníku byly z velké části různé pro respondenty $\mathrm{v}$ závislosti na odpovědi na první otázku šetrení (kromě demografických): „Použili jste někdy ve své praxi digitální hru/hry (popřípadě pravidelně využíváte)?“. Některé otázky byly poté ponechány stejné, aby bylo možné porovnat odpovědi těch, kteří digitální hry ve své výuce používají a těch, kteří nikoliv.

Data byla překódována do číselné podoby a pak analyzována pomocí deskriptivní statistiky (relativní četnosti, aritmetický průměr). S cílem zjistit souvislost použivání digitálních her ve výuce (u položky „Použili jste někdy ve výuce digitální hru/hry?“) s vybranými demografickými charakteristikami respondentů (kategoriálními proměnnými) byl použit test nezávislosti chi-kvadrát, umožňující porovnat očekávané četnosti s pozorovanými. Statistické výpočty byly provedeny v programech Excel a SPSS verze 24.

\subsection{Oblasti dotazniku}

V rámci šetření bylo stanoveno šest výzkumných otázek, kdy jednotlivé položky dotazníku spadaly do oblastí definovaných těmito otázkami.

${ }^{5}$ http://nezzazvoni.cz/mapa-skol/ 
1. Jaké problémy vnímají učitelé ve spojitosti s používáním digitálních her ve výuce?

2. Liší se vnímání digitálních her u učitelů, kteří používají digitální hry ve výuce a kteří nikoliv?

3. Jaký je dle učitelů vztah žáků ke hrám?

4. Jak jsou digitální hry používány ve vztahu s probíranou látkou?

5. Pomocí jakého ICT vybavení jsou digitální hry využívány ve výuce?

6. Je mezi používáním digitálních her a jednotlivými demografickými charakteristikami učitelů (pohlaví, věk...) souvislost?

Dotazník je tedy členěn do šesti oblastí, které pokrývají různá témata, týkající se zapojování digitálních her do výuky, popř́ípadě řeší jejich vztah k žákům, učivu nebo obecněji k ICT vybavení a dovednostem.

Oblast č. 1 - Demografické otázky

Do této oblasti jsou zařazeny otázky, které zjišt'ují respondentův věk, pohlaví, místo (kraj, velikost obce), jaké předměty na škole vyučuje a jak dlouhá je jeho pedagogická praxe. V oblasti se nacházelo pět otázek, z toho jedna dichotomická, tři uzavřené a jedna polouzavřená.

Oblast č. 2 - Využívání digitálních her ve výuce

Otázky zařazené do této oblasti zjišt'ují, jaké hry respondent ve výuce používá, jak často a k jakému účelu. Oblast byla operacionalizovaná za pomocí pěti polouzavřených otázek, jedné uzavřené a dvou výroků hodnocených na Likertově škále.

Oblast č. 3 - Vztah her a žáků

Pomocí dvou polouzavřených otázek a dvou výroků jsme se zde učitelů ptali, jak žáci hry ve výuce hrají, který typ žáků dle jejich názoru nejvíce těží z této metody a jaký vliv má zapojení digitálních her na motivaci, soustředění a chování žáků v hodině.

Oblast č. 4 - Vztah her a učiva

Oblast se zabývá především tím, nakolik jsou hry propojené s ŠVP a na kolik se učitelé domnívají, že hry prospěly žákům ve zlepšení jejich znalostí v rámci daného předmětu. Tato data jsou zjišt'ována jednou polouzavřenou otázkou a dvěma výroky hodnocenými Likertovou škálou.

Oblast č. 5 - Problémy spojené s digitálními hrami

Oblast je zaměřena především na zjištění překážek při zapojování digitálních her do výuky a obsahuje větší množství výroků na téma rozličné komplikace, které se objevují i v zahraničních výzkumech uvedených výše ${ }^{6}$ (nedostatek času, problémy s chováním, málo dostupných her, nedostatek financí a podobné). Jedná se o nejšíř́eji operacionalizovanou oblast, bylo zde využito dvou polouzavřených otázek a devíti výroků hodnocených na Likertově škále.

Oblast č. 6 - Problematika ICT

Vzhledem k tomu, že digitální hry úzce souvisí s ICT vybavením školy, je i zde začleněno několik otázek na ICT vybavení školy a jejich využívání v rámci výuky. ICT ovšem není podstatou tohoto výzkum, otázek tedy není mnoho a slouží spíše k dokreslení celkové situace. Tyto kontextové informace byly zjišt'ovány třemi polouzavřenými

${ }^{6}$ Futurelab, 2009; Ruggiero, 2013; Takeuchi \& Vaala, 2014; Watson \& Yang, 2016 
otázkami. Sledované téma bylo operacionalizováno pomocí dvou dichotomických, šesti uzavřených, třinácti polouzavřených otázek a dvaceti výroků hodnocených na Likertově škále.

Spolehlivost výzkumného nástroje byla ověřena pomocí hodnoty Cronbachovo alfa. U oblasti, kde byly použity otázky Likertova typu, jsme spočítali reliabilitu za všechny položky pro jednotlivé skupiny respondentů rozdělených dle otázky, která zjištovala, zda hry používají či nikoliv. V př́ípadě respondentů, co hry používají, byla reliabilita výrazně vyšší $(\alpha=0,7)$ než u skupiny respondentů, co hry nepoužívají $(\alpha=0,44)$. Hraniční hodnota pro Cronbachovu alfa je 0,7 (Cronbach, 1951). Hodnoty mezi 0,5 a 0,7 je pak možné brát jako akceptovatelné, pokud se jedná o předvýzkum, nebo pokud je šetření provedeno v zemi poprvé (Bendermacher, 2010, Cortina, 1993), což je i př́ípad tohoto výzkumu. Nízkou reliabilitu u „nehrajících“ si vysvětlujeme tak, že si respondenti nebyli jistí v odpovědích, zatímco supina hráčů má asi jednotnější názor na problematiku, daný osobní zkušeností.

\subsection{Respondenti}

Účastníci výzkumného šetření byli vybráni ze základních škol v rámci celé České republiky. Základním souborem tohoto výzkumu byli učitelé základních škol prvního i druhého stupně. Do konečného výběrového souboru se vyplněním dotazníku dostalo 586 respondentů.

Genderové složení respondentů bylo dle očekávání (a současné situaci v českých školách). Většinu tvořily ženy $(81,23 \%)$ a menší část muži $(18,77$ \%). Nejčastěji pak odpovídali učitelé s delší praxí (15-30 let praxe - 36,18 \%), nejméně pak učitelé s nejdelší praxí (více jak 30 let -16,21\%), dále viz Tabulka 1.

\begin{tabular}{|l|r|r|}
\hline Odpověd' & Počet & \\
\hline Genderové rozložení & 476 & $81,23 \%$ \\
\hline Žena & 110 & $18,77 \%$ \\
\hline Muž & 212 & $36,18 \%$ \\
\hline Učitelská praxe & 176 & $30,03 \%$ \\
\hline 15 - 30 let & 103 & $17,58 \%$ \\
\hline 5 - 15 let & 95 & $16,21 \%$ \\
\hline 0 - 5 let & \multicolumn{2}{|c|}{} \\
\hline Více jak 30 let & 81 & $13,82 \%$ \\
\hline Kraj působnosti respondenta & 75 & $12,80 \%$ \\
\hline Středočeský kraj & 65 & $11,09 \%$ \\
\hline Hlavní město Praha & 56 & $9,56 \%$ \\
\hline Jihomoravský kraj & 52 & $8,87 \%$ \\
\hline Jihočeský kraj & 39 & $6,66 \%$ \\
\hline Kraj Vysočina & 34 & $5,80 \%$ \\
\hline Moravskoslezský kraj & 32 & $5,46 \%$ \\
\hline Olomoucký kraj & 28 & $4,78 \%$ \\
\hline Ústecký kraj & \multicolumn{2}{|}{} \\
\hline Plzeňský kraj & \multicolumn{3}{|c|}{} \\
\hline
\end{tabular}




\begin{tabular}{|c|c|c|}
\hline Královéhradecký kraj & 28 & $4,78 \%$ \\
\hline Zlínský kraj & 27 & $4,61 \%$ \\
\hline Liberecký kraj & 26 & $4,44 \%$ \\
\hline Pardubický kraj & 24 & $4,10 \%$ \\
\hline Karlovarský kraj & 19 & $3,24 \%$ \\
\hline \multicolumn{3}{|l|}{ Velikost obce } \\
\hline $10000-50000$ obyvatel & 209 & $35,67 \%$ \\
\hline Do 10000 obyvatel & 171 & $29,18 \%$ \\
\hline Nad 500000 obyvatel & 72 & $12,29 \%$ \\
\hline $50000-100000$ obyvatel & 71 & $12,12 \%$ \\
\hline $100000-500000$ obyvatel & 63 & $10,75 \%$ \\
\hline \multicolumn{3}{|l|}{ Vyučovací předměty respondenta } \\
\hline $\begin{array}{l}\text { Více předmětů v rámci učitelství } \\
\text { prvního stupně }\end{array}$ & 170 & $29,01 \%$ \\
\hline Cizí jazyk & 158 & $26,96 \%$ \\
\hline Matematika & 134 & $22,87 \%$ \\
\hline Český jazyk & 92 & $15,70 \%$ \\
\hline Informatika & 80 & $13,65 \%$ \\
\hline Výtvarná výchova & 77 & $13,14 \%$ \\
\hline Občanská výchova & 76 & $12,97 \%$ \\
\hline Zeměpis & 73 & $12,46 \%$ \\
\hline Přírodopis & 66 & $11,26 \%$ \\
\hline Fyzika & 63 & $10,75 \%$ \\
\hline Svět práce & 63 & $10,75 \%$ \\
\hline Dějepis & 62 & $10,58 \%$ \\
\hline Hudební výchova & 53 & $9,04 \%$ \\
\hline Chemie & 33 & $5,63 \%$ \\
\hline Tělesná výchova & 20 & $3,41 \%$ \\
\hline TV & 12 & $2,05 \%$ \\
\hline Výchova ke zdraví & 7 & $1,19 \%$ \\
\hline Jiné & 24 & $4,08 \%$ \\
\hline
\end{tabular}

Tab. č. 1: Shrnutí demografických údajü.

U krajů byla snaha o co největší rovnoměrnost, nicméně jak můžeme vidět v Tabulce 1, rozdíl mezi nejvíce (Středočeský kraj - 13,82 \%) a nejméně (Karlovarský kraj - 3,24 \%) zastoupeným krajem je poměrně značný. Za povšimnutí stojí i zjištění, že nejčastěji odpovídali učitelé prvního stupně $(29,01 \%)$, popř́padě že se na dotazník rozhodlo odpovědět i více učitelů tělesné výchovy.

\section{Výsledky výzkumu a diskuze}

Klíčovou otázkou dotazníku byla první otázka (po demografických) „Použili jste někdy ve výuce digitální hru/hry (popř́padě pravidelně využíváte)?“, která pro 
respondenta dotazník dále rozdělila a pokládala následně jiné otázky každé skupině některé otázky ovšem zůstaly stejné, je tak možné v některých ohledech skupiny porovnat. Obě skupiny byly téměř rovnocenné ( $51,02 \%$ - Ne, $48,98 \%$ - Ano), což se dá považovat za poměrně povzbuzující výsledek vzhledem $\mathrm{k}$ tomu, že o problematice zapojování digitálních her do výuky se mnoho nehovoří. Pokud omezíme response dle délky učitelské praxe, můžeme pozorovat pokles využívání digitálních her spolu s růstem délky praxe, nicméně pokles mezi první a poslední skupinou není nijak výrazný (Tabulka 2). Signifikance je zde hraniční $\left(\mathrm{p}=0,05, \mathrm{X}^{2}=7,84\right)$ proto nelze říct, že by délka praxe souvisela s používáním digitálních her.

\begin{tabular}{|l|r|r|}
\hline Délka praxe & Ano & Ne \\
\hline $0-5$ let & $57,28 \%$ & $42,72 \%$ \\
\hline $5-15$ let & $52,84 \%$ & $47,16 \%$ \\
\hline $15-30$ & $45,75 \%$ & $54,25 \%$ \\
\hline Více jak 30 let & $40 \%$ & $60 \%$ \\
\hline
\end{tabular}

Tab. č. 2: Délka praxe respondenti̊

Stejně byly zjištovány signifikance u souvislosti používání her a dalších demografických proměnných, kdy statisticky signifikantní byl pouze vztah respondentů ke kraji, ve kterém působí $\left(\mathrm{X}^{2}=\mathrm{p}<0,05\right)$. U ostatních sledovaných proměnných rozdíl nebyl signifikantní: pohlaví $\left(\mathrm{p}=0,09, \mathrm{X}^{2}=2,96\right)$, velikost obce $\left(\mathrm{p}=0,42, \mathrm{X}^{2}=3,93\right)$.

5.1 Využiváni digitálních her ve výuce

Otázka, která byla položena pouze těm, kteří odpověděli kladně, odhaluje, že největší část dotázaných $(48,08 \%)$ využije digitální hry jen několikrát během školního roku a druhá největší skupina dotázaných $(25,44 \%)$ ji využije několikrát do pololetí. Mimo očekávání je také fakt, že většina dotázaných, kteří použili či používají hry ve výuce, sami nejsou hráči v soukromém životě (jen třetina dotázaných 31,71 \% jsou aktivní hráči).

Vzhledem k relativně nízké produkci specifických titulů je zajímavé, že nejčastěji jsou používané výlučně hry vzdělávací, určené pro konkrétní předmět $(71,78 \%)$. Nemalá část respondentů použivá jak hry určené pro vzdělávání, tak běžně dostupné komerční hry $(24,04 \%)$, a kombinuje jejich použití dle účelu. Jen velice malé procento se pak zaměřje především na komerční hry $(2,79 \%)$, a to i přes jejich větší obecnou známost, snazší dostupnost i podporu v odborné literatuře (viz Adams, 1998; Tannahill et al, 2012; Short, 2012 a další).

Vzhledem k tomu, že šetření bylo kvantitativní, lze jen spekulovat nad tím, jaké konkrétní vzdělávací tituly učitelé využívají. Nicméně lze dovodit, že spíše jednoduché procvičovací hry, jelikož jako expozici nové látky využivá digitální hry jen $15 \%$ dotázaných, zatímco většina $(70,83 \%)$ právě k procvičení. Nemalá část učitelů využívá hry k ověření žákovských znalostí (44,25\%). Je možné, že pokud by hra, jakožto relativně zábavný element, byla častěji nasazována $\mathrm{k}$ testování (i hodnocení) žákovských znalostí, nebyla by pro žáky zkušenost s ověřováním jejich znalostí natolik stresující a nepř́ijemná. Nejčastěji pak k ověření žákovských znalostí využívají hry učitelé cizích jazyků.

Zajímavý je i rozdíl v nasazování her do výuky ve smyslu jejich distribuce žákům. Nejčastěji jsou hry hrány bud’ samostatně, kdy každý žák hraje hru sám (46,34 \%), nebo 
hru hraje třída dohromady jako celek $(28,22 \%)$ pravděpodobně prostřednictvím projektoru nebo interaktivní tabule. Hraní her ve skupinkách se vyskytuje také $(20 \%)$, ovšem další možnosti, jako je sít'ová hra více hráčů $(2,44 \%)$ a podobně jsou již vyloženě minoritní.

V této oblasti byly také použity dva výroky hodnocené dle Likertovy škály. Konkrétně otázka, zda učitelé považují hry za stejně vhodné jako jiné metody výuky, byla položena (ve stejném znění) oběma skupinám rozděleným na ty, co používají a ty, co nikoliv. $\mathrm{V}$ odpovědích můžeme najít rozdíl mezi jednou a druhou skupinou, nicméně odmítnutí skupinou „,nehrajících“ není tak silné jak by se dalo čekat (signifikance: $p=0,42 \mathrm{X}^{2}=16,45$ ). $\mathrm{S}$ výrokem, že digitální hry jsou stejně vhodné, tak souhlasí (souhlasím a spíše souhlasím) $69 \%$ učitelů, co hry používají a $31,5 \%$ těch, co nikoliv, přičemž $33,1 \%$ nehrajících nedokáže tuto skutečnost posoudit.

Druhý výrok byl již čistě pro první skupinu dotázaných a ptal se, zda dle jejich názoru hry pomáhají probíranou látku lépe vizualizovat. Zde se většina dotázaných domnívala, že ano (56,45\% - spíše souhlasím, $19,86 \%$ - souhlasím).

5.2 Vztah her a žáků

Důležitá otázka byla, zda učitelé ve své praxi vypozorovali, jaký typ žáka nejvíce těží ze zapojování digitálních her do výuky. Většina respondentů se domnívá, že v tom není rozdíl a situace je u všech žákủ stejná $(47,74 \%)$, ovšem nemalá část vidí digitální hry jako prŕnos spíše pro znevýhodněné žáky, a to především méně výkonné $(22,65 \%)$ nebo žáky $\mathrm{s}$ výchovnými problémy $(8,36 \%)$. Ostatně není to překvapující, protože pro méně výkonné žáky může být hra motivující a příjemný faktor, jelikož v ní selhání často není nijak fatální element a není tolik ponižující, jako při jiných aktivitách. Pro žáky s výchovnými problémy mohou být hry lákavé také $\mathrm{z}$ důvodu větší interakce s učivem.

Velice povzbuzující pro celou oblast vzdělávacích her je výsledek otázky, zda je zde vnímán větši zájem studentů o vyučovací předmět jako takový, když jsou použity digitální hry. To je ostatně zmiňováno i v jiných studiích (např. Futurelab, 2009; Hwang, et al., 2012), je však pozitivní, že si toho všímají samotní učitelé (Obrázek 1).

Použiváni digitálnich her ve výuce vede $\mathrm{k}$ většímu zájmu žákủ o predmět jako takový.

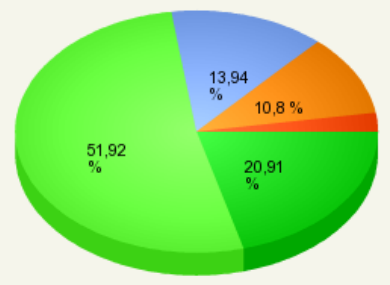

प souhlasim: $60(20,91 \%)$

口spis̄e souhlasim: $149(51,92 \%)$

口nevim: 40 (13,94\%)

$\square$ splše nesouhlasim: $31(10,8 \%)$

$\square$ nesouhlasim: $7(2,44 \%)$

Obr. č. 1: Zájem žákư při použití dig. her. 
Pozitivní respondenti hodnotili i dopad her na motivaci žáků, kdy s výrokem ,,Studenti jsou více motivovani k práci, když jsou použity digitální hry "ve valné většině souhlasili (Obrázek 2). K podobným zjišstěním ostatně docházely i výše zmíněné studie ze zahraničí, kde jsou výsledky podobné (Hiller, et al., 2016; Ke, 2008a; Anetta, et al., 2008 a další), a to jak ve vztahu $\mathrm{k}$ okamžité motivaci (práce v hodině př̀ zapojení dig. her), tak i $\mathrm{k}$ větší motivovanosti žáka k dlouhodobější koncentrované práci.

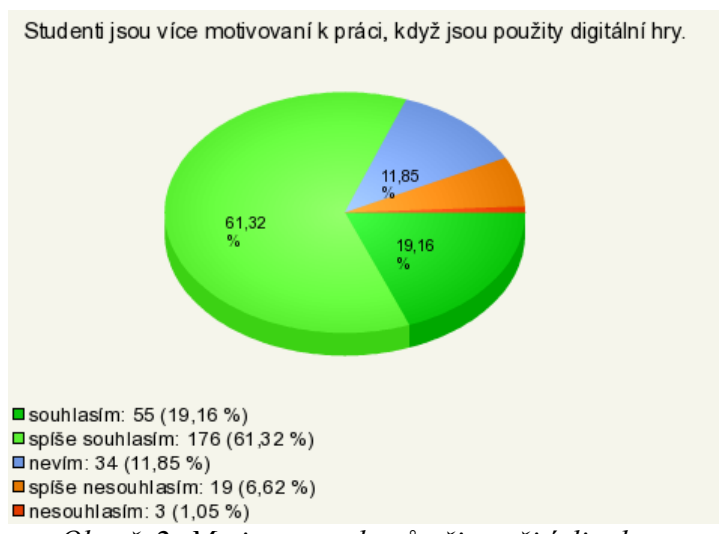

Obr. č. 2: Motivace studentů při použití dig. her.

\subsection{Vztah her a učiva}

Dle odpovědí respondentů lze říci, že je velká snaha používat hry v souladu s kurikulem. Ve větší míře sice volněji $(36,6 \%)$, ale poměrně často se respondenti vyjadřují, že jejich použití přesně pokrývá kurikulum. Naopak právě hry, které s učivem vủbec nesouvisejí, používá jen výrazná menšina dotázaných (3,14 \%) - (Obrázek 3).

I když nemalá část učitelů použivá hry $\mathrm{k}$ ověrení žákovských znalostí, největší část dotázaných neví, jestli $\mathrm{k}$ lepším výsledkům hry pomáhají (40\%). Přibližně stejně velká část učitelů (cca $40 \%$ ) vnímá zlepšení v kurikulárních znalostech právě díky zapojení her do výukového procesu.

Do oblasti spadala i otázka položená výhradně té skupině respondentů, která hry nepoužívá, a sice jestli se domnívají, že digitální hra je pouze prvek zábavný bez vzdělávacího potenciálu. Většina s výrokem spíše nesouhlasila (46 \%), což je pro digitální hry slušný výsledek vzhledem $\mathrm{k}$ tomu, že jsou často brány právě jen jako zábavný prvek. 
Do jaké miry souvisi hry, které použiváte s kurikulem?
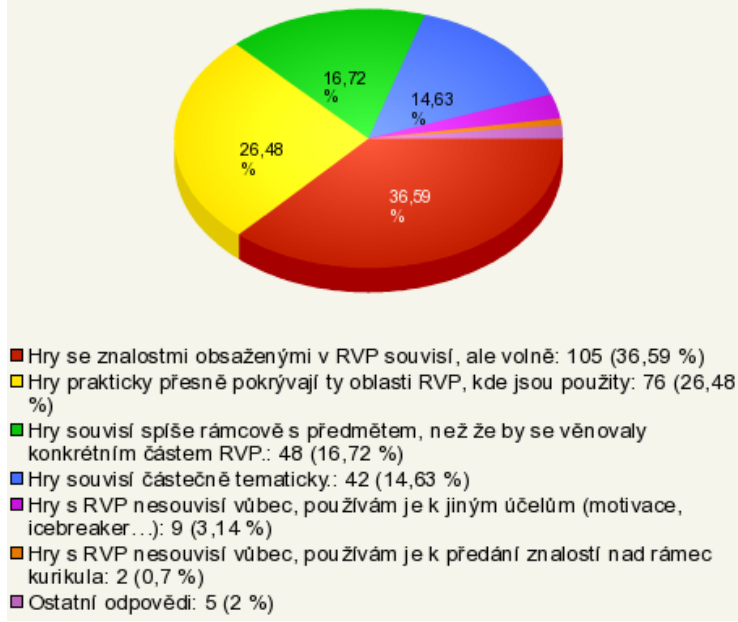

Obr. č. 3: Míra souvislosti her a kurikula.

\subsection{Problémy spojené s digitálními hrami}

Vzhledem k tomu, že digitální hry u nás nemají velkou oporu v didaktikách jednotlivých předmětů ani v odborné literatuře, dají se očekávat problematické situace a překážky, které budou znesnadňovat, či přímo bránit nasazení digitálních her. Mưže se jednat o limity technické, finanční, kázeňské nebo znalostní. Vzhledem k tomu, že všechny možné překážky je potřeba co nejlépe popsat, aby bylo možné s hrami ve výuce efektivně pracovat v budoucnu, je tato oblast poměrně obsáhlá.

Jedna z hlavních otázek této oblasti cílila na nalezení nejpalčivějších problémů, které zažívali učitelé, kteří hry do výuky aktivně nasazovali. Nejčastějším problémem $(49,48 \%)$ byl nedostatek času ve výuce, což ovšem může znamenat problémy pro jakoukoliv výukovou metodu, která je náročnější na exekuci v hodině. Je také možné, že učitelé často volí sice poutavé, ale časově náročné hry, které jsou vhodnější pro domácí práci. Problémem může být i nedostatečná hodinová dotace $\mathrm{k}$ tomu, aby bylo možné pracovat pomocí časově sice náročnějších, ale zajímavějších postupů. Pozitivní také je, že velká část dotázaných žádné zásadní problémy nevnímá $(31,71 \%)$. Nedostatečné (v tomto případě ICT) vybavení škol $(22,65 \%)$ je také setrvalý problém a bude se asi velice různit dle možností a ochoty zřizovatele školy. Poměrně dobrá zpráva je, že se učitelé mnoho neobávají negativní reakce rodičů $(5,57 \%)$ nebo ostatních kolegů $(3,5 \%)$. Je nad rámec této práce posoudit, jestli se hry ve společnosti natolik etablovaly, že rodiče nebudou skeptičtí vůči této metodě, nebo jestli jsou důvody jiné.

Obdobná otázka byla položena i respondentům, kteři hry ve výuce nepoužívají. Odpovědi zde byly samozřejmě jiné, podstatou bylo zjistit, jaké důvody učitelé mají pro nepoužívání her. Nezájem o problematiku je samozřejmě validní důvod, kupodivu se 
objevoval poměrně zř́dka. Jako největší překážku vnímali respondenti stejný problém jako jejich kolegové, kteří již hry ve výuce aplikovat zkoušeli, tedy nedostatek času v hodinách $(45,48 \%)$ a nedostatečné technické vybavení $(31,77 \%)$. Respondenti často naráželi i na nedostatek informací o možnostech digitálních her $(42,47 \%)$, což je jistě oblast, která je poměrně málo saturovaná. Naopak méně respondentů se obávalo neklidu ve trrídě $(15,72$ $\%)$ nebo nevhodnosti her jako média pro vyučovaný předmět $(10,37 \%)$.

Oblast také obsahovala řadu výroků jak pro skupinu co použíá digitální hry, tak pro ty, kteří je nepoužívají. Mezi respondenty, kteří používají digitální hry, je patrný poměrně pozitivní př́stup $\mathrm{k}$ problematice. Je vidět, že nedostatek materiálů, času a informací je opravdu ten nejzásadnější problém, který se podařilo odhalit. Obavy z kázeňských obtíž́i nebo z nesoustředěnosti žáků při použití her jsou spiše liché, mezi respondenty to nejsou nijak zásadní problémy (Tabulka 3).

Průměrný skór ve vnímání problémů spojených s dig. hrami u respondentů, kteří používají digitální hry, se blížil $3(x=2,87, \mathrm{SD}=0,38)$, jednalo se tedy spíše o neutrální vnímání. Respondenti, kteří hry nepoužívají, jsou také spiše neutrální, nicméně více se přiklání $\mathrm{k}$ souhlasu $\mathrm{s}$ negativním hodnocením $(x=2,43, \mathrm{SD}=0,31)$. Největší obavy u respondentů, kteří s hrami ve své praxi zkušenost nemají, panují z návykovosti hraní her ( $90 \%$ - souhlasím, spíše souhlasím) a jejich odtrženosti od reality (89 \% - souhlasím, spíše souhlasím), což jsou témata, která se často objevují i v médích.

\begin{tabular}{|l|r|r|r|r|r|}
\hline Otázka & Souhlasím & $\begin{array}{l}\text { Spíše } \\
\text { souhlasím }\end{array}$ & Nevím & $\begin{array}{l}\text { Spíše } \\
\text { nesouhlasím }\end{array}$ & Nesouhlasím \\
\hline $\begin{array}{l}\text { Je těžké udržet tř́idu } \\
\text { soustředěnou, když } \\
\text { používám digitální } \\
\text { hry. }\end{array}$ & $6,27 \%$ & $21,60 \%$ & $6,62 \%$ & $49,83 \%$ & $15,68 \%$ \\
\hline $\begin{array}{l}\text { Domnívám se, že je k } \\
\text { dispozici jen velice } \\
\text { málo materiálů o } \\
\text { výuce s digitálními } \\
\text { hrami. }\end{array}$ & $26,13 \%$ & $38,68 \%$ & $21,60 \%$ & $13,24 \%$ & $0,35 \%$ \\
\hline $\begin{array}{l}\text { Většina her má jen } \\
\text { velice malou spojitost } \\
\text { s kurikulárními } \\
\text { znalostmi. }\end{array}$ & $7,67 \%$ & $27,87 \%$ & $34,84 \%$ & $26,83 \%$ & $2,79 \%$ \\
\hline $\begin{array}{l}\text { Je velice náročné } \\
\text { digitální hry nasazovat } \\
\text { z důvodu nedostatku } \\
\text { času v hodinách. }\end{array}$ & $31,01 \%$ & $45,30 \%$ & $3,83 \%$ & $16,38 \%$ & \\
\hline $\begin{array}{l}\text { Nevím, kde dobré hry } \\
\text { pro výuku hledat. }\end{array}$ & $21,60 \%$ & $36,93 \%$ & $6,27 \%$ & $26,48 \%$ & $3,48 \%$ \\
\hline $\begin{array}{l}\text { Používání digitálních } \\
\text { her v rámci výuky } \\
\text { vede k problémům s } \\
\text { chováním. }\end{array}$ & $1,05 \%$ & $10,10 \%$ & $11,50 \%$ & $57,14 \%$ & $20,21 \%$ \\
\hline
\end{tabular}

Tab. č. 3: Problémy při nasazeni dig. her. 


\subsection{Problematika ICT}

I když zjišt’ování stavu ICT na školách není cílem této práce, je to prvek, jenž ovlivňuje právě i možnosti nasazení digitálních her. $Z$ tohoto důvodu výzkumné šetření obsahovalo několik otázek zaměřených tímto směrem.

Obecná otázka zjišt'ovala, jaké ICT prvky mají učitelé pro výuku na školách k dispozici. Dle očekávání jsou k dispozici především stolní počítače (89 \%) a přenosná zařízení (tablet: 32,6 \%, notebook: 31,6 \%), což by v rámci použití digitálních her bylo dostačující. Je zajímavé, že přes všechny pobídky jak ze strany státu, tak EU, je zde velice malá saturace interaktivními tabulemi (jen $7 \%$ ).

Ti, kteří digitální hry ve výuce využívají, pak nejčastěji použijí právě stolní počítač (65 $\%$ ), interaktivní tabuli (52\%) nebo tablety (18,5\%). Na druhou stranu ta část respondentů, která hry nevyužívá, nejčastěji sáhne po počítači s projektorem $(67,2 \%)$, využije počítačovou učebnu (11,7\%), nebo ICT ve své výuce vůbec nevyužívá (10 \%). Interaktivní tabule, tablety a další moderní prvky ICT zde prakticky chybí.

\section{Závěr}

Výsledky výzkumu, zaměřeného na zjištění stavu využívání digitálních her v základním školství, i názory učitelů na tuto problematiku naznačují, že digitální hry mají poměrně slušnou šanci stát se do budoucna plnohodnotným výukovým nástrojem. Skoro polovina respondentů hry alespoň jednou za čas využívá a překážkou není ani věk učitelů, jelikož použití s léty praxe klesá jen velmi málo.

Největší problémy pak nejsou společenské, které jsou obtížně řešitelné (nesouhlas rodičů, kolegů), ale jsou spíše technického a informačního rázu. Nedostatečný čas hry zařazovat $\mathrm{v}$ hodinách by se dal řešit vhodnou př́pravou i informacemi, jak co nejekonomičtěji hry do výuky zapojit. I z odpovědí respondentů, kteří s hrami zkušenosti nemají, vyplývá, že zde nejsou nijak silné negativní předsudky vůči této metodě, spíše pochopitelné obavy nebo jednoduše nezájem.

Dotazníkové šetření se nicméně potýkalo s několika problémy, které je nutné adresovat. V prvé řadě nebyla zcela optimální návratnost dotazníku. Nižší návratnost je ovšem do jisté míry ovlivněna dočasnou nebo trvalou nedostupností některých adres, uvedených na webových prezentacích jednotlivých škol. Dalším problémem je reliabilita výsledků. Ačkoliv lze poměrně s jistotou říci, že dotazníky vyplnili respondenti ze zvoleného základního souboru (tedy učitelé základních škol), je zde možnost toho, že častěji vyplnili dotazník učitelé, kteří mají ke hrám silnější vztah, at' už negativní nebo pozitivní.

Srovnání s výzkumy citovanými v začátku této studie je samozřejmě obtížné, protože od zmíněných zemí nás dělí jiný kulturně-sociální a ekonomický vývoj, data však nejsou v souvislosti s obdobnými položkami významně rozdílná. Např́iklad v citované nedávné americké studii (Takeuchi \& Vaala, 2014) je uvedeno, že s hrami ve vyučování má zkušenost již $74 \%$ z dotázaných pedagogů, což je jistě více jak v této studii, nicméně americké školy mají zkušenosti již ze 70. let 20. století. Zde jsou výsledky této studie podobné spíše Singapurskému stavu z roku 2012 (Koh, et al., 2012), popřípadě poněkud problematické americké studii z roku 2013 (Ruggiero, 2013). Podobné jsou i výsledky typů her a dalších. Zajímavé je, že v zámoří jsou nejpoužívanější hry v hodinách matematiky, zatímco v našich podmínkách nacházejí častěji uplatnění v jazykovém 
vzdělávání. Pozitivní zjiššení je také to, že zatímco v některých studíích (např. Watson \& Yang, 2016) se často objevuje jako velký problém kázeňské zvládání žáků při zapojení her, tento problém čeští učitelé př́liš nevnímají.

Tato studie je prvním krokem $\mathrm{k}$ dalšímu zjišt'ování možností a cest, jak efektivně digitální hry využít ve školním vzdělávání. Další studie by měly následovat a dotvořit tak obraz tohoto výukového nástroje. Bez ohledu na podporu ze strany akademické obce či vzdělávacích institucí, budou vyučující patrně zkoušet digitální hry zapojovat do své praxe a to tím spíše, čím více mladých studentů učitelství bude nastupovat do své první praxe. Je proto nasnadě, pokusit se vytvořit co možná nejlepší podmínky k tomu, aby mohly být digitální hry využity co možná nejefektivněji ku prospěchu jak žáků, tak učitelů.

\section{Literatura}

Adams, Paul,C. Teaching and learning with SimCity 2000. Journal of geography. 1998, roč. 97, č. 2, s. 47-55. ISSN 00221341.

Alanne, K. (2016). An overview of game-based learning in building services engineering education. European Journal Of Engineering Education, 41(2), 204-219.

Annetta, L. A., Minogue, J., Holmes, S. Y., \& Cheng, M. -T. (2008). Investigating the impact of video games on high school students' engagement and learning about genetics. Computers \& Education, 53(1), 74-85.

Basl, J., Boudová, S., \& Řezáčová, L. (2014). Národní zpráva šetření ICILS 2013: počítačová a informační gramotnost českých žáků. (1. vyd., 57 s.) Praha

Bendermacher, N. (2010). Beyond alpha: Lower bounds for the reliability of tests. Journal of Modern Applied Statistical Methods, 9(1), 95-102.

Brom, C., Šisler, V., \& Slavík, R. (2010). Implementing digital game-based learning in schools: augmented learning environment of 'Europe 2045'. Multimedia Systems, 16(1), s. 23-41.

Calongne, \& Hiles, J. (2007). Blended Realities: A Virtual Tour of Education in Second Life. Proceedings of TCC Worldwide Online Conference 2007. (s. 70-90). TCCHawaii.

Can, G., \& Cagiltay; K. (2006). Turkish Prospective Teachers' Perceptions Regarding the Use of Computer Games with Educational Features. Educational Technology \& Society, 9 (1), 308-321.

Cortina, J. M. (1993). What is coefficient alpha? An examination of theory and applications. Journal of Applied Psychology, 78(1), 98-104.

Cronbach, L. J. (1951). Coefficient Alpha and the internal structure of tests. Psychometrika, 16(3), 297-334.

Denner, J., Werner, L., \& Ortiz, E. (2012). Computer games created by middle school girls: Can they be used to measure understanding of computer science concepts?. Computers, vol. 58(issue 1), pp. 240-249.

Deveau, J., Lovcik, G., \& Seitz, A. R. (2014). Broad-based visual benefits from training with an integrated perceptual-learning video game. Vision Research, 99, 134-140.

Dieker, L., Rodriguez, J., Lignugaris/Kraft, B., Hynes, M., \& Hughes, C. (2014). The Potential of Simulated Environments in Teacher Education: Current and Future Possibilities. Teacher Education and Special Education: The Journal of the Teacher Education Division of the Council for Exceptional Children, 37(1), s. 21-33. 
Felder, R. M., \& Silverman, L. K. (1988). Learning styles and teaching styles in engineering education. Engineering Education, 78(7), 674-681.

Futurelab. (2006). Teaching with games: COTS games in the classroom. Transforming Learning Experiences.

Gee, J. (2004). What video games have to teach us about learning and literacy. New York: Palgrave Macmillan

Hamilton, G., Ortega, R., Hochstetler, V., Pierson, K., Lin, P., \& Lowes, S. (2014). Teaching Communication Skills to Hospice Teams: Comparing the Effectiveness of a Communication Skills Laboratory With In-Person, Second Life, and Phone Role-Playing. American Journal of Hospice and Palliative Medicine, 31(6), s. 611-618. DOI: 10.1177/1049909113504481.

Hiller A. Spires, James C. Lester, (2016) "Game-based learning: creating a multidisciplinary community of inquiry", On the Horizon, Vol. 24 Iss: 1, pp. $88-93$

Hsiao, H. -S., \& Chen, J. -C. Using a gesture interactive game-based learning approach to improve preschool children's learning performance and motor skills.

Hwang, G. -J., Sung, H. -Y., Hung, C. -M., Huang, I., \& Tsai, C. -C. (2012). Development of a personalized educational computer game based on students' learning styles. Educational Technology Research And Development, 60(4), 623-638.

Chang, K. -E., Wu, L. -J., Weng, S. -E., \& Sung, Y. -T. (2012). Embedding game-based problem-solving phase into problem-posing system for mathematics learning. Computers \& Education, 58(2), 775-786. http://doi.org/10.1016/j.compedu.2011.10.002

Interactive software federation Europe (ISFE). (2012). Videogames in Europe: 2012 Consumer Study. Videogames in Europe: Consumer Study 2012. Dostupné z: http://www.isfe.eu/videogames-europe-2012-consumer-study

Karadag, R. (2015). Pre-service Teachers' Perceptions on Game Based Learning Scenarios in Primary Reading and Writing Instruction Courses. Educational Sciences: Theory \& Practice, 15(1), 185-200.

Ke, F. (2008)a. Computer games application within alternative classroom goal structures: cognitive, metacognitive, and affective evaluation. Educational Technology Research And Development, 56(5), 539-556.

Ke, F. (2008)b. A case study of computer gaming for math: Engaged learning from gameplay? Computers \& Education, 51(4), 1609-1620.

Koh, E., Kin, Y. G., Wadhwa, B., \& Lim, J. (2012). Teacher Perceptions of Games in Singapore Schools. Simulation \& Gaming, 41(1), 51-66.

Miller, D. M., \& Robertson, D. P. (2009). Using a games console in the primary classroom: Effects of "brain training" programme on computation and self-esteem. British Journal of Educational Technology, 21(2), 242 -255.

Pastore, R. S., \& Falvo, D. A. (2010). Video Games in the Classroom: Pre-and in-service teachers' perceptions of games in the K-12 classroom. Instructional Technology and Distance Learning, 7(12), 49-61.

Philpot, T., Hall, R., Hubing, N., \& Flori, R. (2005). Using games to teach statics calculation procedures: Application and assessment. Computer Applications in Engineering Education, 13(3), s. 222-232. DOI: 10.1002/cae.20043. 
Prensky, Marc. Digital Natives, Digital Immigrants Part 1. On the Horizon. 2001, roč. 9, č. 5, s. 1-6. ISSN 1074-8121. DOI: 10.1108/10748120110424816. Dostupné z: http://www.emeraldinsight.com/10.1108/10748120110424816

Proctor, M. D., \& Marks, Y. (2013). A survey of exemplar teachers' perceptions, use, and access of computer-based games and technology for classroom instruction: the origin, evolution, and impact of doi moi. Computers \& Education, 62(2), 171-180.

Robertson, Judy a Cathrin HOWELLS. Computer game design: Opportunities for successful learning. Computers. 2008, roč. 50, č. 2, s. 559-578. ISSN 03601315. DOI:10.1016/j.compedu.2007.09.020. Dostupné http://linkinghub.elsevier.com/retrieve/pii/S0360131507001078

Ruggiero, D. (2013). Video Games in the Classroom: The Teacher Point of View'. In Games for Learning workshop of the Foundations of Digital Games conference, Chania, Greece.

Short, D. (2012). Teaching scientific concepts using a virtual world - Minecraft. Teaching Science, (58), s. 55-58.

Schnotz, W. (2002). Towards an Integrated View of Learning from Text and Visual Displays. Educational Psychology Review, 14(1), 101-120.

Šisler, V., Brom, C., Cuhra, J., Cinátl, K., \& Gemrot, J. (2012). Stories from the History of Czechoslovakia, A Serious Game for Teaching History of the Czech Lands in the 20th Century - Notes on Design Concepts and Design Process. 11th International Conference, ICEC 2012, Bremen, Germany. s. 67). Berlin: Springer Berlin Heidelberg.

Taekman, J. M., \& Shelley, K. (2010). Virtual Environments in Healthcare: Immersion, Disruption, and Flow. International Anesthesiology Clinics, 48(3), 101-121.

Takeuchi, L. M., \& Vaala, S. (2014). Level up learning: A national survey on teaching with digital games. New York: The Joan Ganz Cooney Center at Sesame Workshop.

Tannahill, N., Tissington, P., \& Senior, C. (2012). Video Games and Higher Education: What Can "Call of Duty" Teach Our Students?. Frontiers in Psychology, 3(210), DOI: 10.3389/fpsyg.2012.00210.

Tannahill, N., Tissington, P., \& Senior, C. (2012). Video Games and Higher Education: What Can "Call of Duty" Teach Our Students? Frontiers In Psychology, (3), -.

Tüzün, H., Yılmaz-Soylu, M., Karakuş, T., İnal, Y., \& Kızılkaya, G. (2008). The effects of computer games on primary school students' achievement and motivation in geography learning. Computers \& Education, 52(1), 68-77.

Watson, W., \& Yang, S. (2016). Games in Schools: Teachers' Perceptions of Barriers to Game-based Learning. Journal Of Interactive Learning Research, 27(2), 153-170.

Zheng, D., \& Young, M. (2006). Teachers' Perceptions of Video Games: MMOGs and the Future of Preservice Teacher Education. Innovate: Journal Of Online Education, 2(3). 